\title{
"Patchy Patriarchy" and the Shifting Fortunes of the CCP's Promise of Gender Equality since 1921
}

Harriet Evans ${ }^{*}$

\begin{abstract}
The CCP's commitment to gender equality since 1921 has produced vast gains in employment and education for countless women while overlooking established gender hierarchies in family life. Long-term research in Beijing reveals that crossing class, sectoral and generational differences, there is an apparent paradox between women's increasing access to education and employment and their abiding attachment to ideas and practices associated with their roles as wives, mothers and daughters-in-law. A reconfigured "patchy" form of patriarchy is sustained by a dominant discourse of gender difference that naturalizes women's association with the domestic sphere. Unprecedented engagements with international feminism after 1995 introduced new approaches to gender equality. Recently, young feminists from diverse backgrounds have launched public protests targeting expectations of women in marriage and family life, marking a contestation of previous articulations of gender equality. Online platforms are flooded with exchanges about women's empowerment in a market environment that grants them considerable leverage to manage their marital and domestic relationships. The focus of this new generation of feminists on social reproduction signifies a radical departure from the classical Marxist principles underpinning earlier approaches to women's emancipation. Nevertheless, a "patchy patriarchy" continues to characterize widely held gender assumptions and expectations, spanning class and sectoral difference.
\end{abstract}

Keywords: China; Beijing; Dashalar; gender equality; patriarchy; feminism

\section{A Brief Historical Overview}

Inheriting the Chinese Communist Party's (CCP) early formal commitment to the "liberation of women," the first Marriage Law of the People's Republic of China (PRC) in 1950 enshrined "equal rights of men and women" (nannü quanli pingdeng 男女权利平等) as one of the key principles of China’s social revolution.

* University of Westminster, London, UK. Email: evansh@westminster.ac.uk. 
Within the space of a few years, a new generation of women were celebrating their historic ascendance to the stages of publicly, socially recognized labour and education, and through this, their new identity as men's equals. Considerable empirical evidence demonstrates the dignity, sense of purpose and political loyalty to the progressive vision of the new PRC state that women's public presence as socialist subjects gave them. ${ }^{1}$ Decades later, the nostalgia for the earlier socialist era demonstrated by women who came of age during the 1950 s opened up a "space for women of this cohort to remember themselves as creative political actors" in an environment which, by the late 1990s, denied them this ability. ${ }^{2}$ Women's domestic and familial responsibilities did not significantly feature in discussions about women's emancipation, to the point that the general tenor of official commentary on “woman-work” (funü gongzuo 妇女工 作) in the early 1950s was implicitly disdainful of women's domestic work. In a tightly controlled media and discursive environment, many (if not all) women similarly referred to their public roles in claiming their equal status to men. As Wang Zheng argued long ago in this journal, women overlooked references to their domestic and familial responsibilities, since these played no part in women's new status markers as equal to men. ${ }^{3}$

One prominent result was an uneven and structurally discriminatory gender division of labour that left women shouldering a "double burden" - as members of the social labour force and as the major carers of children and the elderly, with the lion's share of domestic tasks. The CCP acknowledged the reality of this double burden but remained wedded to the standard Marxist view that economic independence through paid labour established the necessary material foundations for women's emancipation from the economic bonds tying them to the "men's family." 4 The journals of the Communist Youth League and the Women's Federation (ACWF) published numerous articles advising women on how to "resolve the contradiction between domestic chores and work." The initial assumption was that the state would eventually replace the household as the main provider of childcare and domestic services. ${ }^{5}$ Cai Chang 蔡畅, the first chair of the ACWF, opined that women should accept "their chief responsibility for the home" until that state was in a position to "resolve the contradiction between domestic chores and work."6 In the meantime, as Jiping Zuo comments, "women's negotiations constantly revolved around the tensions between fulfilling state demands and meeting family needs."7 Until the state was wealthy enough

1 Evans 2008; Hershatter 2011; Liu 2007; Wang 2010.

2 Rofel 1999, 131.

3 Wang 2010.

4 Wolf 1972.

5 Many letters published in the journals of the Women's Federation and/or the Communist Youth League in the 1950s were critical, even despairing, about the inadequacy of domestic and welfare services. An example was an article published under the title of "Duomo nan dang de mama" (How difficult it is to be a mum) in Zhongguo qingnian 9(1 May 1956), 5-7. See Evans 1991, 270.

6 Cai Chang 1957, 3, quoted in Evans 2007, 107.

7 Zuo 2013, 121. 
to take on such tasks, it was "natural" for women to continue in this role. A Shanghai publication on Talking about the Marital Relationship (Tantan fuqi guanxi 谈谈夫妻关系) put it very clearly: “A wife's labour is not wasted if she methodically handles domestic affairs, brings up the children to be sweet and loveable, frugally and efficiently manages the household expenses, makes tasty food and keeps the house clean and tidy, because in this way she helps her husband to work even better and contributes to marital harmony." 8 Women's biologically given role to have children was so deeply and uncritically inscribed in CCP policies that failure to fulfil this "natural duty" was considered socially irresponsible. ${ }^{9}$ Hence, while official discourse no longer recognized motherhood and wifehood as the major subject positions with which women should identify, fulfilling their "natural" roles was presented as women's necessary contribution to the collective good. Even though women were legally and politically repositioned as equal to men, their gender responsibilities continued to be largely - if often indirectly - defined with major reference to the interests of husbands, children and the older generation. One effect was women's own denigration of their domestic and familial roles. ${ }^{10}$ Hence, while under the CCP's policies towards women spectacular strides were made in women's employment and education, transforming the conditions of women's and family lives, these were nevertheless constrained by the CCP's historical failure to address women's domestic role.

Pathbreaking works in the 1980s critiqued the failure of the revolution to fundamentally address the familial structures and practices sustaining unequal relationships and how these panned out within the domestic environment. ${ }^{11}$ More ethnographically based research, particularly since the 1990s, has added to these early arguments in examining how different cohorts of women, distinguished by class, sector and education, lived and experienced official policies of gender equality by engaging in employment and collective political activities, alongside the dominant "naturalization" - that they invariably internalized - of their domestic roles as the major carers of children and the elderly. Evidence of family and marital tensions, exhaustion and neglect of children were, without doubt, in part at least, the bodily and emotional effect of the burden that working, and often highly educated, women shouldered in their identification with the world of work and political involvement as the source of their newfound recognition in the public sphere. ${ }^{12}$ It is certainly possible to argue that such embodied and emotional effects were a form of "resistance" to gendered expectations of their "service" to the family (and state). Come the Cultural Revolution, as Liu Jieyu has documented, some, maybe many, women working in factories as machine operators and administrative personnel did indeed feel that their work

8 Sun 1958, as quoted in Evans 1991, 152.

9 Evans 1997, 122.

10 Liu 2007; Evans 2008; Wang 2010.

11 Stacey 1983; Wolf 1985.

12 Evans 2008. 
practices were unfair, with wages that were invariably lower than their husbands' and being overlooked for promotion despite meeting the necessary requirements. ${ }^{13}$ While their tone in describing such inequities was sometimes sarcastic, none of them linked this "unfairness" to "gender inequalities." 14

In the rural sphere, in collective agricultural labour, the gender difference between women and men was marked, starting with disparities in the work-point system with women being allocated tasks deemed to be physically less demanding therefore more suitable for naturally weaker women. At the same time, so Gail Hershatter argues, "the operative assumption was not gender equality, but gender difference"; women were understood and saw themselves as naturally responsible for domestic tasks, to the point that "difference was so much a part of the taken-for-granted, commensense arrangements that it merited virtually no comment." 15

Into the 1990s, as private ownership and enterprise began to take off in the urban sector, many women of the older cohorts found themselves being prematurely retired or laid off. Just as women in the mid-1950s had been exhorted to "return home" in order to alleviate pressure on the urban labour force, they once again found themselves as the sacrificial victims of economic strategy. Official statistics reveal that by the end of 1997, across the country, women constituted 62.8 per cent of the laid-off workers, while they accounted for less than 39 per cent of the total urban workforce. ${ }^{16}$

Against this backdrop, the Fourth World Conference on Women, which Beijing hosted in 1995, proved to be a watershed moment for many educated, professional Chinese women, including academics and Women's Federation personnel. They had unprecedented opportunities to engage with women from all over the world, particularly the Global South. They learnt about how women's organizations elsewhere had been tackling issues of poverty, health and education in conditions constrained by often challenging structures and practices of patriarchal authority. They also came across new understandings of gender removed from the biological underpinnings of gender difference that they had grown up with. There was a palpable excitement as women began to debate the emancipatory message of a notion of gender as a social construct, and therefore susceptible to change. Many publications followed, as did the establishment of women's studies centres and courses, with varying degrees of association with the Women's Federation. ${ }^{17}$ While this growing feminist voice was not consistently or completely backed by the Women's Federation, it nevertheless signalled the beginnings of a shift in conceptualizations of gender and sexuality through engagement with international feminism.

13 Liu 2007.

14 Thanks to Liu Jieyu for these comments, made in personal correspondence in March 2021, about the tone and demeanour of the women she interviewed in her Gender and Work.

15 Hershatter 2011, 145.

16 Wang 2000, 65.

17 Hershatter 2007, 99-102. 
Into the new millennium, spectacular societal changes in China as it joined tracks with global capitalism generated new challenges as well as opportunities for women. Increased social differentiation and changing employment structures gave many women access to unprecedented prospects of self-realization, achievement and recognition, but they also increased practices of gender discrimination under widening gender disparities. By 2017, China ranked 100th out of 144 countries in the World Economic Forum's Global Gender Gap Index. ${ }^{18}$ Under Xi Jinping's 习近平 revival of China's national heritage of Confucianism, dominant discourse and policy have shifted towards an explicit celebration of women's domestic virtues and an increasingly marginal place for "gender equality" in the language of the party-state, including the Women's Federation.

Alongside these developments, a new generation of young feminists from diverse backgrounds including LGBTQ+ activism have begun to target marriage and family responsibilities as well as women's public status in exploring feminist ideas that signal a radical departure from previous principles of women's emancipation and gender equality. The threat this activism is seen to signal to the status quo of China's male-dominated political system has not curbed the explosion of online platforms for exchanges about women's empowerment in a market environment that grants them considerable leverage to manage their marital and domestic relationships. Leta Hong Fincher argues that women's growing awareness of their rights alongside their rejection of marriage and childbearing "could imperil the government's most urgent population-planning objectives" and hence China's social stability. ${ }^{19}$ Nonetheless, there are few observable signs among the many wealthy and highly educated female millennials of a fundamental shift away from a continuing identification with fundamentally conservative gender arrangements. ${ }^{20}$

In sum, through the spectacular achievements of the CCP and the party-state in transforming the conditions of women's lives over the past century, what I have called a "patchy patriarchy" continues to characterize gendered expectations of and assumptions about marital and family relationships. ${ }^{21}$ Across class, generational and sectoral differences, patriarchal structures in China have long since relinquished their "classic" features, summarized as "a hierarchical system of domestic relations that includes multiple intersecting structures of inequality including gender and generational inequalities, among others." 22 Nevertheless, these have been repeatedly reconstituted through shifts in the political economy throughout the Mao era and beyond into the post-reform globalized market economy. They have long been sustained by a discourse of gender difference centring on, although far from limited to, matters of marriage, reproduction, family, kinship, female virtue and the domestic division of labour. 
Across disparities of education, profession and generation, this has fed into an uneven reconfiguration of ideas and practices about appropriate gender behaviour, mediated by culturally and historically embedded expectations of gender roles and shored up by sociobiological assumptions about natural gender differences. "Traditional" expectations of a woman's performance as wife, mother and daughter-in-law have, as noted above, been given a significant discursive boost under Xi Jinping's government in its explicit encouragement to women to identify with their "natural" roles, legitimizing these with reference to the importance of China's Confucian heritage in sustaining social stability. Played out in popular culture in the form of TV soaps, commercial advertisements and much more, the critical spaces available to women to explore alternative possibilities of gender are severely constrained. Why and how some young urban women are drawn to feminist challenges to the dominance of marriage while others belonging to what appears to be the same sociological category make compromises with normative marriage expectations is a question that further research needs to take up.

\section{Dashalar Families}

I now turn to shed light on these arguments by briefly revisiting the disadvantaged neighbourhood of Dashalar 大栅栏 in central Beijing's "South City" (nan cheng 南城), just a stone's throw south of Tiananmen Square. ${ }^{23}$ As some of the poorest of Beijing's population, Dashalar's long-term residents belong to a social sector not included in mainstream analyses of women and gender in China. Yet, from their very distinct social positionality, they confirm the gender paradox that I argue characterized most if not all women's privileging of gender difference over gender equality throughout the Mao years and beyond. The specific form this paradox took in the lives of the Dashalar women I knew was highlighted by their conditions of hardship, scarcity and precarity. However, it would be a mistake to imagine that there was a simple causal link between their material conditions of scarcity and their attachment to patriarchal-type practices, for an equivalent paradox is demonstrated in different forms by highly educated, wealthy women of the post millennial urban elite, as Xie Kailing demonstrates. ${ }^{24}$ In their different ways, mediated by class positioning, both can be understood, in part at least, as gendered responses to structural and discursive characteristics of the party-state's framing of nannü pingdeng 男女平等.

Most of the people I knew in Dashalar lived in the small lanes and alleys off the main shopping street of the neighbourhood, in the dilapidated conditions of "big cluttered courtyards" (dazayuan 大杂院), which they had occupied for several decades. Born there, growing up there, getting married and having

23 For a fuller exposition of the process and aims of this research, mainly carried out between 2006 and 2014, see the "Introduction" in Evans 2020. I wish to acknowledge my deep gratitude to the late Zhao Tielin, the Beijing-based photographer, who initially introduced me to his friends in the neighbourhood, and to his assistant, Huang Mingfang, with whom I continued to work after Zhao's passing.

24 Xie 2021. 
children there, they were poor, deprived and mostly only minimally educated. A number of the men were unemployed or semi-employed in the informal economy, while the women worked long hours as cleaners in local restaurants or public conveniences. The courtyards where they lived had long ago been subdivided and filled in with single room dwellings to accommodate the capital's growing population. Some of them housed up to 12 or even more families. By 2005, they all had electricity and a television, but no washing facilities or hot water, and only a small stove burner, which served as their kitchen.

Few knew much about life outside the capital. Old Mrs Gao, who was already in her mid-80s when I first got to know her in 2006, had never left Dashalar since marrying into it in 1937. Most of the neighbourhood's children had managed to move out, either by finding jobs or marrying men in other neighbourhoods. The dazayuan and their nearby lanes were therefore focal centres of sociality, informal employment and social identification, where particularly older and middle-aged local people spent most of their time. In physical, spatial, social and cultural terms, Dashalar was, literally, the place bounding their everyday lives and social relationships. Nevertheless, while in many ways my interlocutors' stories were spatially framed by conditions of existence that had changed very little since the early 1950s, women's lives had been radically transformed by the employment policies of the Mao era that formally legitimated them as workers in the public sphere. To me - the outside analyst - their attachment to conservative gender arrangements and relationships suggested a conspicuous inconsistency with their independent assertiveness as major income earners. To ground this argument, I turn to two subaltern families, only one of which was still living in the neighbourhood the last time I visited it in 2017.

The first time I met Old Mrs Gao, she had just come home from hospital where she had spent two weeks recovering from pneumonia. Her husband had died some years before I met her, but her children's comments suggested that they had long regarded her as the emotional mainstay of her household. Her infirmity did not diminish this role. People used to come and go, often seeking her advice about this and that, or accompanying her as she dozed, chatting, drinking and smoking cigarettes. Her long life, her determination to keep her family going, and her reputation for generosity to neighbours down on their luck made her the linchpin of her family's unity and survival.

Old Mrs Gao became bedridden in 2009. Very thin and frail, she spent her days on the big bed in the main living space of her home, lying back against a pillow, knees raised in front of her, looking at the television on the dresser in front of her, dozing or just looking around. Her youngest son, Young Gao, had a chronic lung condition that made him unfit for regular employment, so he spent most of his time with his mother, sitting at the small table by her bed. Since Xiao Xi, his wife, was often out at work, he was left to care for his mother, helping her with the bedpan, and rearranging her position to make her comfortable. Xiao $\mathrm{Xi}$ undertook these tasks as soon as she returned from work; she also did the daily shopping for food, the cooking, tidying and cleaning. Occasional comments 
Xiao Xi and Young Gao's sisters made about his drinking habits implicitly criticized him for not pulling his weight, but none of them openly reproached him, at least not in my presence.

When I first met Young Gao, his right arm was in a cast after breaking it in a collision with a local rickshaw cyclist. His mother had just come out of hospital. He had previously had a job at a local vegetable depot but was laid off when he was admitted to hospital for an operation. By June 2007, he had been sacked from another job as a night watchman after being discovered drinking while at work. For a brief period, he received the basic welfare payment from the local government, but he largely depended on his wife's income. In 2007, she, Xiao $\mathrm{Xi}$, worked as an unlicensed pedicab driver until pedicabs and itinerant street vendors were officially ordered off the streets as part of the neighbourhood's "beautification" before the 2008 Olympics. She then found a job in a factory, where she used to work six night shifts every week.

$\mathrm{Xiao} \mathrm{Xi}$ was an extremely capable and hardworking woman, as well as a dutiful daughter-in-law and wife. She also had an independent spirit, demonstrated on one occasion in going against her husband's wishes to visit Tiananmen Square in late May 1989 to find out what was going on. Yet, despite the contrast between her resilience and her husband's evident weakness, she was deferential to her husband. She would wait on him, and serve him his food, and if from time to time she would tell him not to drink too much, she never directly criticized him. Occasional comments she made indicated that she was aware of the potential affront to her husband's authority that her employment and income might imply. Nevertheless, the reasons for her deference were far from clear, and it was only when Young Gao died in late 2010, and when negotiations about Old Mrs Gao's relocation began, that I came to understand more about the apparent contradictions in Xiao Xi's behaviour.

One morning in the summer of June 2009, Young Gao seemed unusually depressed and had lost a lot of weight. He had had another spell in hospital to treat fluid on his lungs. Although it was only ten in the morning, he had already started drinking strong sorghum spirits. His mother's condition had deteriorated, and financial difficulties were on his mind. But there was another reason for his distress. He had been quarrelling with his eldest sister, had not slept well and woke up thinking about his father's death a few years before. Young Gao had developed pneumonia but had tried to ignore his condition so he could look after his father who was then seriously ill in hospital. Eventually, Young Gao also had to be hospitalized, and distressingly, was not released until after his father died.

Old Mrs Gao and her daughters sometimes praised Young Gao for his filial care of his mother, yet neither their attempts to assuage his distress nor his claim that the "Communist Party doesn't let me work" could hide his sense of inadequacy as a husband and son unable to sustain his familial duties. He once remarked that it would have been better had his mother not given birth to him. His distress was compounded by the precarious future his family faced. 
Some, like his wife, were quite pragmatic in their response to the prospect of moving. Young Gao could not, or chose not to, confront the idea; for him it was unimaginable.

Young Gao died unexpectedly in late 2010, but even before then, news was already circulating in Dashalar that the alley where the Gao family lived was going to be widened, meaning the partial demolition of some dazayuan. Within a few months of Young Gao's death, Xiao Xi and her mother-in-law were preparing to relocate to subsidized accommodation provided by the local government. For Xiao Xi, this seemed a better option than the alternatives of accepting compensation and finding their own accommodation, or being rehoused in another dazayuan in the neighbourhood. Given that compensation would be based on the floor area of their Dashalar home, it would not be enough to afford a commercial rent elsewhere, and remaining in Dashalar could only be a temporary measure at best, since sooner or later it would all be demolished, as indeed did turn out to be the case. Old Mrs Gao was more than 90 years old and, at best, only had a few years left to live. Through long negotiations with her in-laws, and despite the discomfort and distress to the old lady, Xiao Xi insisted on relocation under the government's arrangements.

It was at this point that Xiao Xi's interests as a widowed "outsider" in her husband's family, as she put it, came to full light. She hoped that the contract for the new apartment would pass to her after her mother-in-law's death. When Old Mrs Gao eventually died in 2013, Xiao Xi's affinal siblings wanted her to leave the apartment in return for monetary compensation. Xiao Xi insisted that with no alternative residence, and in return for the long years of fulfilling her filial obligations to her mother-in-law, they should respect her moral right to the apartment after her mother-in-law's death. Her deference to her husband, despite his inadequacies, and her filial care of her mother-in-law could be explained in part, at least, as an effect of her dependency on them for her residential and material security. Folded into her material self-interest, however, was also an ethical sense of self, as wife and daughter-in-law of the "man's family." While her husband and mother-in-law were alive, her investment in the trappings of patrilineal authority was rooted both in her pragmatic interests in material returns and in her gendered notion of integrity and "self-worth." The instrumental dimension of her sense of entitlement as a woman was inseparable from her sense of self as a gendered person who was ethically bound to certain forms of conduct.

Through the long decades of her life in Dashalar, and with little apparent support from either her husband or the state, Old Mrs Gao performed the key role of safeguarding her household against fragmentation, along the lines of Charles Stafford's influential argument. ${ }^{25}$ Reaffirming the bitterness of her childhood highlighted her determination to care for her uterine family during the $1950 \mathrm{~s}$ and 1960s, even though it also explained her lowly status as a "dependent 
housewife" (jiashu 家属) outside the formal state system of employment. The bitterness of her past life, therefore, became the reference for a self-legitimation articulated through her role as daughter, mother and wife. Her claim to having fulfilled her family duties was a virtuous vindication of her attachment to ethical and gendered values associated with women's "traditional" roles in implicit contestation of a state that denied her recognition as someone who counted as a social subject.

In contrast, her son's self-validation - or lack of it - was rooted in his sense of failure, as a man, to assume the gendered responsibilities expected of him as husband and son. So, while for his mother the place and space of her home and neighbourhood acquired a sense of interiority as the centre of her performance of her obligations and responsibilities as a woman, for him they had a different meaning. His sedentary occupancy of his home alongside his bedridden mother confirmed his weakness as an uneducated, unemployable man, whose everyday care of his mother should, in the proper gendered order of things, have been the responsibility of his wife. For Xiao $\mathrm{Xi}$, facing relocation, respect for her mother-in-law's and husband's positions offered a path to material security as well as to a sense of integrity as a woman who had fulfilled her obligations to her husband's family.

Hua Meiling lived with her adult daughter in a small room registered under her mother-in-law's name at the back of a dazayuan on the same alley as the Gao family. The room had a double bed, which Meiling shared with her daughter, a small sofa, a computer for her daughter, a television and a small table. It was always tidy and exuded a decidedly feminine feel, with pink cushions and a pink coverlet on the bed, a couple of pictures of cute puppies on the wall, and a lace mat on the small table. Meiling's character presented a striking contrast with this. She was loud, extremely quick-witted, swore like a trooper, chain smoked and drank huge quantities of strong liquor.

Born in another neighbourhood in the late 1950s to cadre parents who worked in a state ministry, Meiling grew up in what she described as a cold and austere family environment. In her eyes, her parents were more interested in their public status than in caring for their children. Her father used to beat his children, and when she finished high school, Meiling ran away from home and fell in with a group of petty criminals who used to offload stolen goods on her for safe keeping. But she wanted to have fun, as she put it, and used to go out to eat with her friends and hang out with boys; she eventually became pregnant and had a painful abortion. Then, in the early 1980s, she was arrested for prostitution and sent for "re-education through labour" for three years. On her release, her parents disowned her. She then found a job in a local pastry factory where she met the man who would become her husband and the father of her daughter. She moved into his mother's dazayuan in Dashalar but then her husband lost his job. He used to beat her and eventually started an affair with another woman. He was then imprisoned for 12 years for violent robbery. Instead of divorcing him, as she said she wanted to, Meiling described how she "ran around after him ... [and] didn't do 
anything to him [she was] sorry about." With a child to bring up on her own, no support from her parents and with little prospect of stable employment, Meiling's main hopes for her own and her child's welfare lay in sustaining her marital links and the material security - in the form of a place to live - that these gave her.

Following her husband's death not long after he was released from prison, Meiling met a man through a neighbour who used to facilitate introductions to "girlfriends." Meiling's new acquaintance ran a small clothes factory and gave her a job there as a cook; she liked him. As a former prostitute with a husband in jail, she had long put up with being the target of neighbours' gossip and, following her husband's death, also had to endure repeated criticism from her mother-in-law and sister-in-law about her lack of filial respect as a daughter-in-law and her failure to give her own daughter, Xiao Hua, a proper upbringing. Meiling was not subdued by such comments and, in conversation with me, often derided her mother-in-law for her gambling habit and her sister-in-law for her loose behaviour. Meiling often said that she would give anything to leave Dashalar, but was prevented from doing so, she claimed, by her mother-in-law's refusal to consider moving. So, constrained by her residential dependence on her mother-in-law, and surrounded by gossip, Meiling welcomed the companionship and care she felt her lover offered her, as well as his protection against the advances of other men. He was also good to her daughter, who called him uncle, even though she rarely saw him since he usually visited when Meiling was on her own. Meiling cooked for him on the single hob in her small room, and always made sure that she looked good. Over 14 years, they had developed a close and companionable relationship, which she did her best to hide from her dazayuan neighbours. She did not want to fuel their gossip about her. "He's got a strong sense of justice, he plays things straight, so after I got to know him, I felt that I would be able to lead a happier life." Despite occasional fights, Meiling felt that her arrangement with her lover constituted a sound exchange: he gave her a monthly contribution towards her and her daughter's expenses, companionship and a sense of self-worth, so she willingly provided the food, warmth and intimacy that both of them seemed to enjoy.

Meiling repeatedly referred to her sense that men were unreliable, but this did not interfere with her insistence that her daughter, Xiao Hua, should find a husband with a stable job: "All I want is that she finds a man with a good job, and as long as she treats him well, and he finds a clean house when he comes home and hot food on the table, he'll be happy." Xiao Hua was only minimally educated, lacked social skills and had little motivation to find work. She liked clothes and make-up and dreamed of doing a cosmetics course. She spent a lot of time online, looking at fashions and films, and although her mother objected, she also spent time surfing dating websites. When I first got to know Meiling, Xiao Hua, then aged 17, had gone off to Fujian with a man she had met online. She eventually returned to Beijng after several months when her boyfriend's parents would not agree to their marriage. By 2011, she had found another boyfriend who not only had a job but access to an apartment. Meiling reserved judgement about whether 
she approved or not. What she was convinced of, however, was that her daughter's security lay in finding a man with prospects on whom she could depend.

Meiling had a succession of short-term jobs between 2007 and 2014, preferring this, she said, to relying on the meagre welfare payments from the local government. She had to work long hours, arriving at work on her bike early in the morning and returning home in time to make dinner for herself and her daughter. She was constantly worried about her daughter's activities while she was out at work, but as the only breadwinner, had little choice but to leave her alone. She never talked with her daughter about her past, but she was explicit in asserting her independence, energy and self-reliance, and felt that Xiao Hua respected her for her hard work and care.

Meiling's status as a single mother living with her daughter removed her from the need to accommodate the physical presence of a senior male, but pragmatic considerations about her residential security tied her to her husband's family. The same pragmatic considerations explained her tolerance of her husband, including the long years he spent in jail and his violence towards her. She was proud of her performance as a hard-working single mother who was able to keep going and stand up to a social world that disdained her. At the same time, and despite her history of violent abuse by her father and husband, she continued to rely on men's capacity to offer protection and material security, evident in her advice to her daughter.

Just as Old Mrs Gao's and Xiao Xi's self-legitimation centred on their fulfilment of gendered values of filiality and family obligation, so Meiling repeatedly referred to her sense of virtue as a wife who had stood by her recalcitrant husband, as a committed mother, and as a dependable, if reluctant, daughter-in-law. Almost echoing the "trace of satisfaction" at having fulfilled her duty of care that Gail Hershatter notes in women's stories about motherhood, Meiling constantly reiterated that she was a "good person" who had never let anyone down and who had never harmed anyone. ${ }^{26}$ Her claims to virtue were rooted in her observance of her familial duties. With a history that earned her social disrepute, this virtue became a source of self-validation that she could hurl in the faces of those who disdained her.

These brief vignettes give glimpses of the gender attachments shared by elderly and middle-aged women and men as evidence of what I call "patchy patriarchy" - gendered commitments to male authority that, in the case of these families, were reconfigured in conditions of scarcity and precarity. In contrast, the idea of "nannü pingdeng" did not surface at all in any of the conversations I had over the years with these individuals. In a sense, their narratives demonstrated a subaltern detachment from the terms of the party-state that both framed the material and political conditions of their existence across time and excluded them from access to its promises. Their distance from the terms 
of the party-state could, on the one hand, be inversely interpreted through the lens of Hershatter's now famous category of "campaign time" to denote the association with the temporality of the party-state as exemplified by those closest to its institutions. On the other hand, this distance could be thought of as an indication of the narrative and experiential effects on subalterns of their situation at the internal frontiers of the state, where, as undesirable subjects, they are portrayed as barriers to development, and dealt with through a combination of laissez-faire state neglect and diverse administrative and policing controls. ${ }^{27}$

\section{Paradoxes, Challenges and Change}

\section{From Mao to the millennium}

Throughout the Mao era, women across differences of class and education lived in a social, economic and political environment in which joining the labour force was, with occasional interruptions, both a social obligation and a source of livelihood. Their daughters grew up knowing that their futures involved full-time employment as well as marriage and having children. If the relevant literature about these cohorts of women makes little direct reference to women's views of the role of the CCP-led government in shaping these experiences, it was, I suggest, because, in part at least, in a political and popular environment that excluded consideration of critical alternatives, the presence of the CCP was so omnipresent in framing the material, social and political frontiers of their lives and experiences that it was taken for granted.

Dashalar women's subaltern status at the margins of the party-state's formal institutions of employment and education educes a different explanation for the absence of reference to the $\mathrm{CCP}$ and the party-state in their narratives. Throughout the Mao years, poor women in Dashalar worked in full-time jobs allocated by the state, but in a range of local small-scale manufacturing and repair operations that did not resemble the spatial or organizational characteristics of the dominant work unit (danwei 单位) system. They also worked in shortterm, gendered jobs under a piece-work type system of largely unskilled labour coordinated by the neighbourhood committee. However, this work was not acknowledged as social labour in the formal wage system governing the labour conditions and wages of workers employed in state work units. Women engaged in such activities, like Old Mrs Gao, were officially categorized as "housewife" or "dependent" (jiashu). ${ }^{28}$ This category was, on the one hand, an anachronistic throw-back to the pre-1949 impediments to women's participation in the social labour force, but, on the other, through the early 1950s in particular, it was a term of moralistic and political disdain for "unproductive" women. By the

27 Thanks to the anthropologist Andrea Pia for this formulation.

28 For an early analysis of how urban dwellers such as housewives, unemployed youth and retired workers were organized by the residents' committees to undertake piece-work type activities, see Salaff 1971. 
mid-1950s when the government wanted to relieve pressure on the urban labour force by encouraging women to "return home," the term "jiashu" was remediated as an "official" (though still subordinate) category of political and administrative recognition. As Song Shaopeng puts it, "women entered the public sphere and joined men in production work, while the state at the same time intentionally propagated the traditional gender roles and duties of women in the household." 29

In reality, however, being a dependent "housewife" during the Mao years was not an option, given women's socialist responsibility as members of the social labour forces. This situation began to change in the late 1980s and the 1990s, when, as many unprofitable state factories began to close, large numbers of women were laid off. Moreover, with the rise of a new urban middle class, increasing numbers of women withdrew from the labour force and began to employ "nannies" to look after their children and undertake domestic chores, modifying the class inflections of the term "jiashu." Decollectivization of agriculture and the restoration of the rural household as the basic unit of production and accounting created a "reserve" of cheap labour that fuelled migration to towns and cities, including vast numbers of rural women who were potentially available for private employment as domestic servants and childcarers. The rapid commercialization of the market and labour was making its mark on local people in a more assertive reiteration of a gender division of labour which harked back to practices from before the Mao era and joined forces with practices shaped by the global capitalist economy. In what was a clear tendency towards the feminization of labour in the privatized service industry, more women, including many in Dashalar, became employed in low-paid casual jobs like cleaning floors and washing up in restaurants alongside their domestic and familial responsibilities.

The women I knew in Dashalar rarely complained, overtly, about the pressures they had to endure, but there were certainly tell-tale signs. On one occasion, when Young Gao complained to his wife that she did not do enough cleaning, she retorted "How can I? I'm out at work all day and come home exhausted! If I keeled over having to do the housework as well, then you'd be really scared!" Others fantasized about what life in a completely different environment would be like. Their reticence in making more explicit complaints doubtless masked tensions and desires to which I was not privy.

Despite their indispensable contribution to the household budget, these women seemed accustomed to being denigrated by their husbands, who not infrequently told them that they were stupid and understood nothing. Their response to this, at least in my presence, was deferral to their husbands. Initially, I found this perplexing because it seemed to jar with their resilient independence as wage earners. In time, however, I came to see it as the manifestation of how a deeply felt attachment to ideas about the correct gendered order of things blended into 
instrumental considerations. It was also indicative of these women's desire to be seen to respect their husbands in a gesture of recognition in a social world that, in their eyes, I was certainly part of, and which had long marginalized them for their lack of education and employable skills.

These comments are reminiscent of Deniz Kandiyoti's influential text, "Bargaining with patriarchy," in which she argues that one of the legacies of "classic patriarchy" practised in different ways throughout the Middle East, South and East Asia is women's negotiation with patriarchal practices in order to protect their own and their children's security. She contends that the "patriarchal script" becomes increasingly attenuated as the material bases of classic patriarchy are eroded under the penetration of market forces in rural areas. In China, of course, it was the collective transformation of land ownership and rural production that destabilized - without destroying - the material bases of that script. At the same time, Kandiyoti asserts that as classic patriarchy enters a crisis, many women do all they can to pressurize men to live up to their obligations as a condition of their own willingness to go along with the gendered status quo. Claiming their half of this particular patriarchal bargain - "protection in exchange for submissiveness and propriety" - can be seen as a kind of "passive resistance." 30

While the theme of "patriarchal bargains" is persuasive, it overemphasizes the role of "resistance" and underestimates the affective or subjective attachment across time to deeply held ideas about the ethics of gender difference. For the women I have introduced above, a profoundly ethical sense of self - as wife, mother and daughter-in-law - underpinned their material and instrumental interests in conditions of scarcity and hardship. They recognized the imbalance between themselves and their menfolk as regards to what they did and what they could say. Nevertheless, the gendered boundaries of their social worlds still prioritized male interests over their own. Moreover, in a social, political and cultural environment in which the discourse of nannü pingdeng failed to address the domestic division of labour, they had little access to alternative ideas about gender difference. Neither their ideological outlook nor their sense of moral duty gave them any cause to threaten androcentric interests in order to further their own.

For me, the outside observer, this presented a striking paradox, as I have already noted: on the one hand, a stringent, even fiercely asserted, claim to independence and, on the other, inconsistent but deeply held attachments to conservative ideas about male authority. While Meiling's performance as a hardworking mother relying on her own resources gave her a sense of dignity, her view that male support offered forms of welfare and protection not otherwise available was unmistakably transmitted to her daughter. Far from the classic "model" of patriarchy, this emerged as an uneven reconfiguration of ideas and practices 
centring on, although not confined to, assumptions about marriage, reproduction, family, kinship, filiality and female virtue ordered by an indivisible mix of culturally familiar gendered and generational obligations. Despite revisions over the past half century or so, and shored up by a socio-biological notion of gender difference, this patchy patriarchy has proved resilient to radical change.

Conversely, younger women born since the 1990s gave glimpses of a desire to assert themselves in ways that implicitly challenged the assumptions of their mothers. Between 2006 and 2017, Xiao Hua, Meiling's daughter, had a succession of casual boyfriends, of whom her mother generally disapproved. Then, in 2014, without Meiling's permission, she ran up huge credit card debts, which became a source of dreadful anxiety to her mother when she was threatened with legal proceedings. These decisions of the daughter could be interpreted as signs of "rebellion" against the mother and, as such, an implicit challenge to the mother's assumptions about the correct way of doing things. Yet it was another relationship that became the single most prominent expression of changing gender practices and expectations I came across during my research in Dashalar. This was seen in the behaviour of the son of the only migrant couple I knew in Dashalar, who refused to go along with his parents' expectations of filial care. Through long years of hardship, including several times when they were forcibly repatriated back to Shaanxi, his parents endured abuse, violence and homelessness in order to finance their children, particularly their son, through college. Their expectation was that he would marry, have a child and settle down in Xi'an, not far from their home village to which they would return. He eventually married a young woman they did not like and had a baby son. His wife, however, would not let her parents-in-law care for the new grandson, or even pick him up. Their son was terribly conflicted the last time I saw him when his parents insisted on taking me to see him, his wife and his little baby. He spent our visit rushing between his parents and me in the living room and his young wife and baby in the adjacent bedroom. His wife did not come out, even to say hello. Seen from his aging parents' perspective, their daughter-in-law's refusal to let them care for their grandson was an assault on their understanding and expectation of filial reciprocity and respect. From their daughter-in-law's perspective, however she explained it to herself, she was objectively asserting her desire to be left alone to look after her baby as she decided.

Such choices by younger women are, in part at least, encouraged by the discursive and social environment they inhabit that emphasizes the legitimacy and desirability of individual choice. The embodied enactments of gender they reveal indicate certain instances of contestation of the gender "model" of their elders, through acts of insubordination and dissent indicating small shifts in gendered meanings. In themselves, they do not indicate any association with or even interest in the emancipatory implications of "gender equality" any more than they suggest a departure from previous ideas about gender difference. Nevertheless, they demonstrate definite shifts away from as well as overlaps with their parents' 
examples, reminding us that change in what it means to be a gendered person is an iterative and painful process that does not necessarily address issues of gender per se.

\section{Millennial shifts}

Recent years have seen a number of young women taking up a new feminist mantle. Involving artists, film makers and others, many of whom, if not all, were schooled politically in LGBTQ+ activism, this has, by definition, involved unprecedented transnational debates and exchanges through social media. For some, it has also involved opportunities to travel and further hone their radical feminist politics abroad. One group, in particular, acquired international prominence as the Feminist Five when, after several years of public activity, they were arrested in March 2015 for challenging male privilege by staging street performance protests. ${ }^{31}$ Their attack on heteronormative marriage brought into public view a focus on women's "place" in family and domestic life, which in theoretical terms has been given new life in China by radical feminists' revised theorization of social reproduction. This draws particularly on the work of the feminist theorist and political philosopher Nancy Fraser who, in this context, argues that one of the key social contradictions of capitalism concerns the "splitting off" of reproductive labour from everything else and its relegation to the institutionalized and nonremunerated "domestic sphere." 32 Although historically, through the different stages of capitalism, economic production has been consistently separated from social reproduction, this separation has reached a new phase as global capitalism's drive for unlimited accumulation threatens to destabilize its reproductive processes, thus jeopardizing the social conditions sustaining the capitalist economy.

Drawing on these and other arguments, Angela $\mathrm{Wu}$ and Yige Dong are taking up the theme of social reproduction in their category of "made-in-China feminism," otherwise known as "C-fem." Based on multi-sited ethnographic work between 2012 and 2017, they interrogate what they describe as the "explosive dynamism" of C-fem in the 2010s on the Chinese internet. In this, they distinguish between two strands: "entrepreneurial" feminism, which encourages women "to abandon traditional wifely duties such as submissiveness and self-sacrifice so they may exercise autonomy on the marriage market to maximise their personal returns," and "non-cooperative" feminism, which celebrates autonomous female sexuality and treats market advantage as a means to achieve this. ${ }^{33}$ Its categorization as "non-cooperative" is "because its empowerment of women arises from denouncing the prevalent marketization of the marital institution." 34

Both strands have generated new media outlets and spectacular numbers of online followers, particularly of "entrepreneurial feminism," most notably in 
the form of a controversial "love advice" consultant called Ayawawa, who was banned from Weibo for her insulting remarks about comfort women during the anti-Japanese war. ${ }^{35}$ Suffice it to say, while a debate needs to be opened about the application of the term "feminism" to the entrepreneurial strand, taken together these largely online phenomena significantly destabilize the androcentric underpinnings of China's hegemonic social order by targeting the contemporary marriage market. They also contain the seeds of a theorization of the current moment of feminism in China which neither draws on nor replicates theoretical "models" of feminism elaborated in the Global North. ${ }^{36}$ As such, they hail a new moment in the history of China's feminism which signifies a radical move away from the focus on labour and the public sphere characteristic of all previous stages in the CCP's articulation of the women's movement.

\section{Final Reflections}

As China celebrates the centenary of the $\mathrm{CCP}$, this brief journey through the changing fortunes of "gender" in the CCP's history reminds us of how women's lives have changed through processes that have - to use Judith Butler's term certainly troubled gender, but without the women themselves directly invoking the term or even the notion of "male-female equality." ${ }^{37}$ While from the perspective of policy and dominant discourse, nannü pingdeng has enjoyed an unassailable place in the CCP's canon from its early beginnings, perspectives grounded in women's experiences reveal a different story. Across the different stages of the CCP's history, through the Mao era and beyond into the reform era, successive generations of women from different class and sectoral backgrounds have struggled to accommodate their domestic and family obligations with the socially more privileged demands of their roles in the public sphere. At the same time, without access to possibilities of thinking of gender outside the socio-biological and structural terms of dominant discourse, and embodying practices inherited from a past steeped in expectations of patriarchal authority, many women across different social backgrounds who grew up under Mao's banner lived their gender difference from men as a central part of their self-understanding as ethical persons.

Some women took advantage of the critical debates around 1995 to explore new critical possibilities of gender. These largely included women in academic and/or professional positions, many of whom were directly or indirectly associated with the Women's Federation. Yet, there was no general shift away from the principles of women's empowerment and emancipation underpinning the policies of the Mao era and the first decades of the reform era.

This may now be changing, as increasing numbers of young women from different, and by no means exclusively urban, backgrounds engage in online

36 Thanks to Rebecca Karl for a very helpful discussion about Wu and Dong's work.

37 Butler 2000. 
exchanges in "taking on" the institution of marriage. While some choose to question the legitimacy of the institution of heteronormative marriage, many more wealthy, aspirational and often highly educated young women are deciding to exploit the market and their husbands according to their own interests in an exchange between their performance of "submissive femininity" and material privileges.

Thus, while the century of the CCP's engagement with feminist politics has not produced the gender equality the Party promised, and the language of gender equality has had limited reach in itself beyond those political, professional and media arenas where it has been deployed, there have been significant changes for women, including my Dashalar acquaintances. At the same time, in changed circumstances and with different opportunities for social encounters and mobility, women's, and men's, adherence to long embedded terms of articulation about gender relations and roles have repeatedly reinscribed what appear to be views and practices reiterating previous standards. However, while the durability of social norms emerges through their repeated enactment, this does not mean stasis. This points to Judith Butler's powerful argument about agency and change, that "recurrence does not index a sameness, but rather the way in which the social articulation of the term depends on its repetition." 38 Within the small cracks of difference between each iteration are contained the possibilities of destabilization as well as reassertion of the norms. To what extent the current exploration of $\mathrm{C}$-fem signals the beginnings of a radical challenge to existing patriarchal structures is a topic for ongoing research.

\section{Acknowledgements}

Many thanks to my two external referees and to Tia Thornton for their very helpful suggestions for improvements of the first draft. Thanks also to Rebecca Karl for discussions about the recent "feminist" wave in China, and to Zhang Lisheng for his help with the Chinese abstract.

\section{Conflicts of interest}

None.

\section{Biographical note}

Harriet EVANS is emeritus professor of Chinese cultural studies at the University of Westminster and visiting professor in anthropology at the London School of Economics. Her Beijing from Below: Stories of Marginal Lives in the Capital's Center was published by Duke University in May 2020. Grassroots Values and Local Cultural Heritage in China (Lexington Books), co-edited with Michael Rowlands, is due to appear in August 2021. 


\begin{abstract}
摘 要: 自 1921 年成立以来，中国共产党一直致力于实现性别平等，为无数 女性在就业和教育方面谋取了巨大福祉, 但同时, 也忽视了家庭生活中种 种根深蒂固的性别等级的存在。通过在北京的长期研究, 笔者发现一个看 似吊论的现象, 即不同的行业、阶层和代际的女性在获得更多的教育和就 业机会的同时，依然遵从妻子、母亲和儿媳等身份所包含的理念和行为准 则。由此可见，一种性别差异的权威话语仍维系着某种经过重构的 “支离 破碎的父权”，并将妇女与家庭空间自然而然地关联起来。1995 年以后， 中国的妇女事业开始与国际女性主义产生交流, 并引入了许多关于性别平 等的新思路。近年来, 来自不同背景的年轻女权主义者不断公开发声, 质 疑当下婚姻和家庭关系对女性角色的种种期待, 开启了一场与既往性别平 等主张的辩论。市场经济环境下的女性赋权成为了网络平台中广泛讨论的 议题, 女性在也因此在处理婚姻和家庭关系中获得了更多的话语权和自主 性。新一代女权主义者对社会再生产的关注, 已经彻底背离了早期妇女解 放事业所依据的经典马克思主义原理。尽管如此, 在不同行业, 阶层中广 泛存在的性别观念仍然呈现出支离破碎的的特征。
\end{abstract}

关键 : 中国; 北京; 大栅栏; 男女平等; 父权制; 女权主义

\title{
References
}

Butler, Judith. 2000. Gender Trouble: Feminism and the Subversion of Identity. London: Routledge. Butler, Judith. 2004. Undoing Gender. London: Routledge.

Cai, Chang. 1957. "Gao hao jiawu laodong, zhiyuan guojia jianshe" (Do domestic work well and support state construction). Zhongguo funü 9, 2-5

Evans, Harriet. 1991. "The Official Construction of Female Sexuality and Gender in the People's Republic of China, 1949-1959." PhD diss., University of London.

Evans, Harriet. 1997. Women and Sexuality in China: Dominant Discourses of Female Sexuality and Gender since 1949. Oxford: Polity Press.

Evans, Harriet. 2008. The Subject of Gender: Daughters and Mothers in Urban China. Lanham, MD: Rowman and Littlefield.

Evans, Harriet. 2017. "Patriarchal investments: expectations of male authority and support in a poor Beijing neighbourhood." In Gonçalo Santos and Stevan Harrell (eds.), Transforming Patriarchy: Chinese Families in the Twenty-first Century. Seattle, WA: University of Washington Press, 182-198.

Evans, Harriet. 2020. Beijing from Below: Stories of Marginal Lives in the Capital's Center. Durham, NC: Duke University Press.

Fincher, Leta Hong. 2018. Betraying Big Brother: The Feminist Awakening in China. London: Verso.

Fraser, Nancy. 2016. "Contradictions of capital and care." New Left Review 100(July-August), https://newleftreview.org/issues/ii100/articles/nancy-fraser-contradictions-of-capital-and-care.

Hershatter, Gail. 2007. Women in China's Long Twentieth Century. Berkeley, CA: University of California Press.

Hershatter, Gail. 2011. The Gender of Memory: Rural Women and China's Collective Past. Berkeley, CA: University of California Press.

Kandiyoti, Deniz. 1988. "Bargaining with patriarchy." Gender and Society 2(3), 274-290.

Liu, Jieyu. 2007. Gender and Work in Urban China: Women Workers of the Unlucky Generation. London: Routledge.

Rofel, Lisa. 1999. Other Modernities: Gendered Yearnings in China after Socialism. Berkeley, CA: University of California Press. 
Salaff, Janet Weitzner. 1971. "Urban communities in the wake of the Cultural Revolution." In John Wilson Lewis (ed.), The City in Communist China. Stanford, CA: Stanford University Press, 289-323.

Santos, Gonçalo, and Stevan Harrell (eds.). 2017. Transforming Patriarchy: Chinese Families in the Twenty-first Century. Seattle, WA: University of Washington Press.

Song, Shaopeng. 2006. "The state discourse on housewives and housework in the 1950s in China." Berliner China-Hefte/Chinese History and Society 31, 49-63.

Stacey, Judith. 1983. Patriarchy and Socialist Revolution in China. Berkeley, CA: University of California Press.

Stafford, Charles. 2000. Separation and Reunion in Modern China. Cambridge: Cambridge University Press.

Sun, Ming. 1958. Tantan fuqi guanxi (Talking about the Marital Relationship). Shanghai: Shanghai renmin chubanshe.

Wang, Zheng. 2000. "Gender, employment and women's resistance." In Elizabeth J. Perry and Mark Selden (eds.), Chinese Society: Change, Conflict and Resistance. London: Routledge, 62-82.

Wang, Zheng. 2010. "Creating a socialist feminist cultural front: women of China (1949-1966)." In Harriet Evans and Julia Strauss (eds.), Gender in Flux: Agency and its Limits in Contemporary China. Cambridge: The China Quarterly Special Issues Series 10, Cambridge University Press, $11-33$.

Wolf, Margery. 1972. Women and the Family in Rural Taiwan. Stanford, CA: Stanford University Press.

Wolf, Margery. 1985. Revolution Postponed: Women in Contemporary China. Stanford, CA: Stanford University Press.

Wu, Angela, and Yige Dong. 2019. "What is made-in-China feminism(s)? Gender discontent and class friction in post-socialist China." Critical Asian Studies 51(4). DOI: 10.1080/14672715/2019/ 1656538.

Xie, Kailing. 2021. Embodying Middle Class Gender Aspirations: Perspectives from China's Privileged Young Women. London: Palgrave Macmillan.

Zhuang, Pinghui. 2018. "China's controversial love guru Ayawawa suspended on Weibo over 'comfort women' comments." South China Morning Post, 23 May, https://www.scmp.com/news/china/ society/article/2147319/chinas-controversial-love-guru-ayawawa-suspended-weibo-over.

Zuo, Jiping. 2013. "Women's liberation and gender obligation equality in urban China: work/family experiences of married individuals in the 1950s." Science and Society 77(1), 98-125. 